\title{
Lung biopsy with guillotine cutting needle and biopsy forceps though transdiaphragmatic thoracoscopy in dogs with pulmonary alterations ${ }^{1}$
}

\author{
Letícia M. Fratini2*, Cristiano Gomes ${ }^{3}$, Luciana Queiroga ${ }^{4}$, Fabiane R. Santos ${ }^{2}$, \\ Alexandra P. Fantinatti ${ }^{5}$, Saulo P. Pavarini ${ }^{6}$, Daniel G. Gerardi ${ }^{3}$ and Carlos Afonso C. Beck ${ }^{3}$
}

\begin{abstract}
Fratini L.M., Gomes C., Queiroga L., Santos F.R., Fantinatti A.P., Pavarini S.P., Gerardi D.G. \& Beck C.A.C. 2018. Lung biopsy with guillotine cutting needle and biopsy forceps though transdiaphragmatic thoracoscopy in dogs with pulmonary alterations. Pesquisa Veterinária Brasileira 38(11):2117-2123. Programa de Pós-Graduação em Ciências Veterinárias, Universidade Federal do Rio Grande do Sul, Av. Bento Gonçalves 9090, Agronomia, Porto Alegre, RS 90540-000, Brazil. E-mail: lefratini@gmail.com

Lung diseases are common in small animal clinical routine. Diagnosis is usually affected due to nonspecific symptoms. Imaging features such as radiography and chest ultrasound are acceptable screening tests, although lung biopsy can provides a precise diagnosis. Thus thoracoscopy provides a minimally invasive diagnostic assessment for chest diseases and offers the benefits such as improved illumination and magnification of the image when compared with thoracotomy. In this study we evaluated the transdiaphragmatic thoracoscopic-assisted techniques of lung biopsy with a the guillotine cutting needle and biopsy forceps, in dogs presenting radiographic suspicion on pulmonary tumors. Fourteen dogs regardless of breed, gender, age and body weight admitted at the Hospital of Veterinary Clinics (HCV) of the Veterinary College (FAVET) of Universidade Federal do Rio Grande do Sul (UFRGS), were assessed. Inclusion criteria were presence of nodules on chest radiography and triage tests without changes that could hinder general anesthesia and surgical approach. The animals were positioned in dorsal recumbence and two thoracoscopic ports were established: the first port for working instruments; the second paraxyphoid port for the telescope. Three samples were collected using each sampling method from each lesion or from tumors macroscopically similar whenever their size was less than one centimeter. The samples were sent for histopathological examination in the Veterinary Pathology Laboratory of FAVET/UFRGS. Surgical time was recorded from first incision to wound closure and surgical complications were reported. The dogs were evaluated for the presence of subcutaneous emphysema, hematoma, seroma, local infection and dehiscence. No conversion to open surgery was necessary during the thoracoscopic procedure in any patient. Thoracoscopic assisted biopsy using guillotine needle and biopsy forceps was a safe and fast technique, without perioperative complications. Both devices provided good quality samples for histopathological analysis of lung abnormalities. However the cutting guillotine needle was more efficient especially in larger pulmonary nodules. The transdiaphragmatic access provided optimal approach for both hemithoraces.
\end{abstract}

INDEX TERMS: Lung biopsy, transdiaphragmatic thoracoscopy, dogs, video surgery, lung neoplasm, chest diseases, thoracic surgery.

\footnotetext{
${ }^{1}$ Received on March 12, 2018.

Accepted for publication on March 27, 2018.

2 Post-Graduated course in Veterinary Medicine (PhD), Universidade Federal do Rio Grande do Sul (UFRGS), Av. Bento Gonçalves 9090, Porto Alegre, RS 90540-000, Brazil. *Corresponding author: lefratini@gmail.com

${ }^{3}$ Departamento de Medicina Animal, Faculdade de Medicina Veterinária, Universidade Federal do Rio Grande do Sul (UFRGS), Av. Bento Gonçalves 9090, Porto Alegre, RS 90540-000.
}

\footnotetext{
${ }^{4}$ Veterinarian, Hospital de Clínicas Veterinário, Universidade Federal do Rio Grande do Sul (UFRGS), Av. Bento Gonçalves 9090, Porto Alegre, RS 90540-000.

${ }^{5}$ Autonomous Veterinarian, Hospital Veterinário Pet Support, Av. Plinio Brasil Milano 1135, Higienópolis, Porto Alegre, RS 90520-002.

${ }^{6}$ Departamento de Patologia Animal, Faculdade de Medicina Veterinária, Universidade Federal do Rio Grande do Sul (UFRGS), Av. Bento Gonçalves 9090, Porto Alegre, RS 90540-000.
} 
RESUMO.- [Biópsia pulmonar com agulha cortante guilhotinada e pinça de biopsia por toracoscopia transdiafragmática em cães com alterações pulmonares.] As afecções pulmonares são comuns na rotina clínica de pequenos animais, todavia, por apresentarem sintomas inespecíficos, muitas vezes o diagnóstico dessas doenças torna-se limitado. Recursos de imagem como a radiografia e a ultrassonografia torácica são válidos como exames de triagem, mas somente a biopsia pulmonar pode possibilitar um diagnóstico específico da doença. A toracoscopia fornece um meio minimamente invasivo de diagnóstico para as doenças torácicas e oferece os benefícios de melhor iluminação e ampliação da imagem, quando comparado com a toracotomia. 0 presente estudo teve como objetivo avaliar as técnicas de biópsia pulmonar por meio da agulha cortante guilhotinada e da pinça de biopsia, guiadas por toracoscopia, pelo acesso transdiafragmático em cães que apresentavam imagem sugestiva de nódulo pulmonar em exame radiográfico prévio. Foram utilizados 14 cães, independente de raça, sexo, idade e peso corporal. Somente caninos com nódulos visíveis na radiografia torácica e que apresentaram condições clínicas e laboratoriais de serem anestesiados foram incluídos no estudo. Os cães foram posicionados em decúbito dorsal e foram realizados dois acessos à cavidade torácica: um primeiro portal intercostal, para introdução dos dispositivos de biopsia; e outro portal paraxifoide transdiafragmático para introdução do endoscópio. Com cada instrumento de biopsia foram coletadas três amostras do mesmo nódulo ou de nódulos macroscopicamente semelhantes e próximos quando o tamanho destes era inferior a um centímetro. Posteriormente as amostras foram encaminhadas para exame histopatológico. 0 tempo cirúrgico foi cronometrado da incisão ao fechamento da ferida, etodas as informações foram registradas. No pós-operatório os cães foram avaliados quanto à presença de enfisema subcutâneo, hematoma, seroma, infecção local e deiscência de pontos. Não foi necessário converter os procedimentos toracoscópicos para cirurgia convencional em nenhum dos caninos. Concluiu-se tratar de uma técnica segura, rápida sem complicações trans e pós-operatórias. Ambos dispositivos permitiram aquisição de material suficiente para análise histopatológica das alterações pulmonares, no entanto a agulha cortante guilhotinada apresentou maior eficácia, principalmente, em nódulos pulmonares de maior diâmetro. 0 acesso transdiafragmático mostrou-se eficiente para exploração de ambos os hemitórax.

TERMOS DE INDEXAÇÃO: Biópsia pulmonar, toracoscopia transdiafragmática, caninos, videocirurgia, neoplasma pulmonar, afecções torácicas, cirurgia torácica.

\section{INTRODUCTION}

Pulmonary parenchymal conditions are common in dogs and cats. Pneumonias and neoplasias are some of the main parenchymal diseases. On the other hand, interstitial lung diseases are rarer (Reineiro \& Cohn 2007).

The diagnosis of pulmonary diseases is through complementary examinations such as thoracic radiography, thoracic ultrasonography, computed tomography, magnetic resonance imaging, fine needle aspiration, tracheobronchial (LTB) and bronchioloalveolar lavage (BAL), and bronchoscopy. However, definitive diagnosis is often possible only by histological examination (Withrow 2013). Samples for this examination can be obtained by biopsy performed by thoracotomy, thoracoscopy or percutaneous with guillotine cutting needle (Wilson \& Dungworth 2002, Baez \& Sorenmo 2004, Basso et al. 2010).

Infirmities such as primary and metastatic neoplasm, inflammatory and infectious processes, circulatory disorders and degenerative conditions have their definitive diagnosis through histological examination (Chojniak et al. 2011). In order to perform the biopsy, video-assisted thoracoscopy is recommended because it causes less trauma to the patient when compared to thoracotomy (Saviano \& Tazzioli 1998)

Thoracoscopic, pleuroscopic or video-assisted thoracoscopic surgery (VATS), when compared to thoracotomy, is a safe technique with minimal thoracic wall trauma, causing less pain, reduction of pneumothorax and subcutaneous emphysema, providing rapid recovery of the patient (Solli \& Spaggiari 2007).

Pulmonary biopsy in dogs through thoracoscopy is still poorly studied and usually requires the use of two or three portals and the use of different types of instruments to obtain the tissue sample (Potter \& Hendrickson 1999).

The aim of this study is to describe and evaluate techniques for pulmonary biopsy using guillotine cutting needle and biopsy forceps, guided by thoracoscopy for transdiaphragmatic and intercostal paraxiphoid accesses in dogs presenting a suggestive image of pulmonary nodule on previous radiographic examination.

\section{MATERIALS AND METHODS}

The present study was approved by the Animal Ethics Committees (AECs) of the Rio Grande do Sul Federal University (Universidade Federal do Rio Grande do Sul, UFRGS), through the approval document and under the protocol number 26239. The tutors were previously consulted about the interest in participating in the present study and, in cases of agreement, they were informed about the benefits and possible risks of the procedure.

Fourteen dogs from the routine care of the Veterinary Clinics Hospital (Hospital de Clínicas Veterinárias, HCV) of the Veterinary School (Faculdade de Veterinária, FAVET) of UFRGS, of different races, ages, body weight and both genders, being nine females and five males, were evaluated. The animals included presented radiographic alterations suggestive of pulmonary nodules, with or without clinical signs. Patients with clinical and laboratory abnormalities that prevented anesthetic and/or surgical procedures were excluded.

All dogs underwent general clinical examination and complementary preoperative examinations such as abdominal ultrasonography, thoracic X-rays in three projections, electrocardiogram, echocardiography, hemogram, total platelet count, total plasma proteins, ALT and creatinine.

After previous fasting, the patients received morphine sulfate $\left(0,3 \mathrm{mg} \cdot \mathrm{kg}^{-1}, \mathrm{IM}\right)$ as preanesthetic medication. A wide trichotomy of the abdomen and thorax and intravenous administration of ampicillin sodium (22mg. $\left.\mathrm{kg}^{-1}\right)$ was performed. All animals were pre-oxygenated with $\mathrm{O}_{2}$ at $100 \%$ for 15 minutes before general anesthesia. Anesthetic induction was performed with propofol (4mg.kg-1, IV), followed by the orotracheal intubation. For anesthetic maintenance, isoflurane was used, vaporized in oxygen at $100 \%$. When necessary, the administration of fentanyl ( $\left.5 \mathrm{mcg}_{\mathrm{kg}}{ }^{-1}\right)$ in bolus in the transanesthetic period. Local blockade of intercostal innervation with lidocaine hydrochloride was performed. 
All patients received multiparametric anesthesia monitoring and were placed in supine position, with antisepsis of the thorax and abdomen being performed. The site of choice to insert the trocar was based on the location of the lesion(s) in the thoracic radiograph, usually a caudal intercostal space to the alteration.

A cutaneous incision was made with approximately $0.5 \mathrm{~cm}$ of extension, longitudinally to the ribs. Subsequently, Halsted hemostatic forceps was inserted for intercostal musculature divulsion and pleura perforation, with consequent induction of pneumothorax, in order to reduce the occurrence of iatrogenic lesions to the pulmonary parenchyma in the moment of insertion of the trocar.

A trocar with $5 \mathrm{~mm}$ of diameter was inserted perpendicularly to the thoracic wall progressively. Once the obturator was removed, the insertion of the rigid endoscope with $4 \mathrm{~mm}$ of diameter and $0^{\circ}$ viewing angle was performed. A rapid exploration of the thoracic cavity was performed, and the endoscope was positioned to visualize the diaphragm region for video-assisted insertion of the second trocar, by the transdiaphragmatic paraxiphoid access.

A skin incision of approximately $0.5 \mathrm{~cm}$ was made between the xiphoid appendix and the costal arch, through which a second trocar (2nd portal) of $5 \mathrm{~mm}$ diameter was inserted. After the video-assisted perforation of the diaphragm, the endoscope was removed from its original position (inside the 1 st portal) and repositioned through the 2nd portal. At that time the mediastinal membrane was perforated with the endoscope itself so that it was possible to visualize both hemithorax.

After exploring the thoracic cavity and identification, location and determination of the severity and characteristics of pulmonary nodulations, the pulmonary sampling instruments were inserted sequentially and alternately through the first portal: the biopsy forceps with teeth (1x1), $5 \mathrm{~mm}$ of diameter and $36 \mathrm{~cm}$ of length, and the guillotine cutting needle for soft tissue, semiautomatic Biomedical $^{\circledR}$ of $14 \mathrm{G}$ caliber and with $150 \mathrm{~mm}$ of length (Fig.1). The order of attainment of the samples with each instrument was chosen randomly by the team at the time of the procedure.

Three samples of the same nodule were collected with each biopsy device. Each sample presented approximately $2 \mathrm{~mm}$ of diameter with the forceps and $1 \mathrm{~mm}$ of diameter with the guillotine needle. At the time of the harvest, possible technical difficulties related to the access to the pulmonary surface, handling of instruments and magnitude of the collected fragments were recorded.

Samples were kept in a $10 \%$ buffered formalin solution and then submitted for histological analysis. All samples were evaluated by the same pathologist through the Hematoxylin-Eosin staining technique.

Subsequently, the presence or absence of hemorrhage was verified, and trocars were removed, synthesis of wounds made, paraxiphoid and intercostal with Sultan suture pattern, with monofilament nylon 2-0 thread. The skin was sutured with simple isolated stitches with monofilament nylon 3-0 thread. The negative pressure of the thoracic cavity was reestablished through thoracocentesis.

The surgery was timed from the first incision to the wound closure and any surgical complications or technical difficulties were recorded if present.

The patients received as immediate postoperative medication tramadol hydrochloride $\left(4 \mathrm{mg} \cdot \mathrm{kg}^{-1}, \mathrm{IV}\right)$, dexamethasone $\left(0,25 \mathrm{mg} \cdot \mathrm{kg}^{-1}, \mathrm{IV}\right)$, and enrofloxacin (5mg. $\mathrm{kg}^{-1}, \mathrm{IM}$ ). All dogs were discharged after six hours of observation. Patients were submitted to clinical evaluation at the time of hospital discharge and at 48 hours after the procedure. In this moment, radiographic evaluation of the thorax was also performed. Rectal temperature was measured, possible respiratory changes observed, presence of subcutaneous emphysema, hematoma, seroma, local infection and dehiscence of stitches, which was not evidenced. The operated area was also palpated to evaluate the painful response of the animal.

Tutors were advised to clean surgical wounds with saline solution every 12 hours, and to maintain Elizabethan collar until the stitches were removed seven days later. Oral administration of tramadol hydrochloride (3mg.kg-1 , TID, for 3 days), meloxicam $\left(0,1 \mathrm{mg} \mathrm{kg}^{-1}, \mathrm{SID}\right.$, for 4 days), and enrofloxacin (5mg.kg-1 ${ }^{-1}$ BID, for 7 days) was advised. After seven days from the procedure the dogs were evaluated again, and the skin stitches were removed.

To verify the viability of the samples obtained with the different biopsy instruments, the qualitative analysis of the specimens was made. Surgical procedures were evaluated in terms of time to perform the procedure, frequency distribution of trans and postoperative complications, and technical difficulties in performing the procedure, if found. The quality of the samples obtained, and the data related to the surgical time, frequency distribution of the technical difficulties and possible complications were analyzed descriptively.

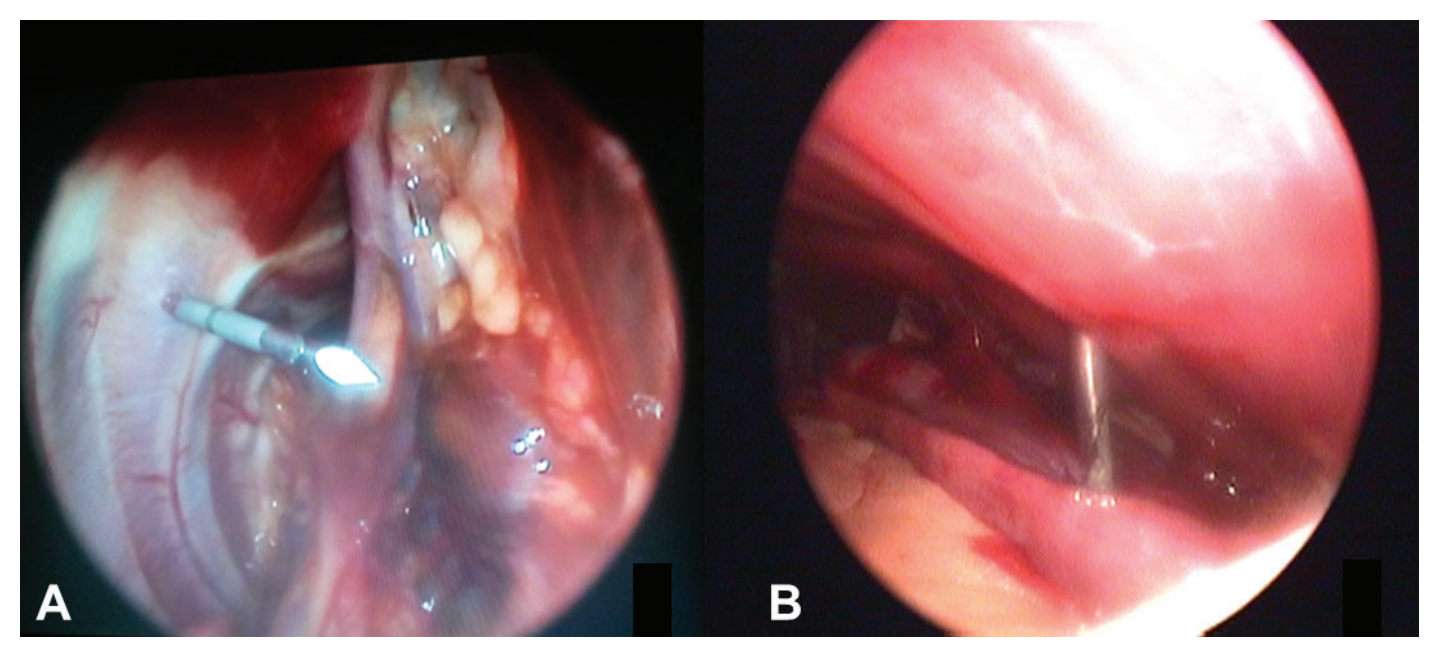

Fig.1. (A) Guillotine cutting needle positioned in the thoracic region to obtain a sample. (B) Biopsy forceps positioned inside the thoracic cavity to obtain a sample. 


\section{RESULTS}

Twenty three dogs with suspicion of pulmonary nodules were evaluated in the period from April to December 2014, in which 9 were excluded because they presented alterations in the complementary exams, totaling 14 patients included in this study.

In pre-surgical thoracic radiography, three dogs (Dog 5, 7 and 14) presented effusion in small amount. None presented pre, trans and postoperative complications. No conversion was required for thoracotomy and all remained alive during the analyzed period.

The mean duration of the procedure was 26.5 minutes (Fig.2). In four dogs (Dog 3, 5, 6 and 7) the portal had to be reinserted into another intercostal space, different from the one planned based on radiography. The option to insert the second portal through the transdiaphragmatic paraxiphoid access guided by endoscopic intercostal visualization was safe, without the occurrence of iatrogenic lesion in any of the 14 animals, allowing wide exploration of the thoracic cavity in both hemithorax and excellent visualization of the pulmonary parenchyma.

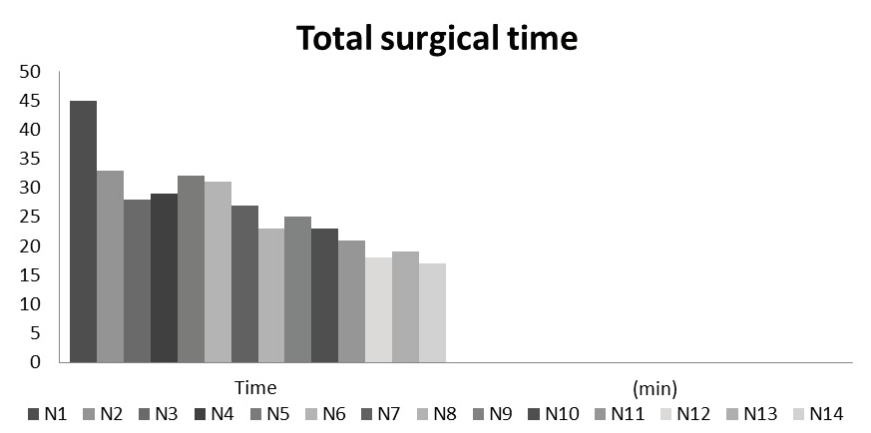

Fig.2. Graphic representation of the surgical time obtained to the biopsy guided by thoracoscopy using biopsy forceps and needle with guillotine cut, in 14 dogs. Evidencing the learning curve with the reduction of surgical time throughout the experiment.
Only one patient presented communication between the hemithorax; in the other 13 dogs (92.85\%), the mediastinal membrane was intact and ruptured with the endoscope during thoracoscopy. Intercostal access for the introduction of biopsy devices was also adequate and made it possible to grasp the tissue without major difficulties.

Regarding the quality of the material collected by each biopsy device, the samples obtained were considered satisfactory, and it was possible to reach the same diagnosis with both the biopsy forceps and the cutting needle in $85.71 \%$ of the cases (Table 1). In two dogs the samples obtained by the biopsy forceps were not representative presenting only a focal area of necrosis, and artifact (atelectasis) by compression of the pulmonary parenchyma.

Little or no bleeding was observed after biopsy. The dogs did not present hematoma, subcutaneous emphysema, infection and pain during palpation at the surgical site within 48 hours until clinical reevaluation. After this period, the animals were submitted to thoracic radiography, and none presented pneumothorax. Dogs 5, 7 and 14 presented a small amount of effusion, which had already been observed in the radiography prior to the procedure.

Referring to the harvesting technique of the nodules sample, both devices tested were efficient in seizing and acquiring the material, obtaining histologically significant samples in $100 \%$ of the animals participating in the study.

\section{DISCUSSION}

Thoracic effusion found in three of the 14 dogs was probably due to pulmonary neoplasms (Fossum 2008). Thoracoscopy was a safe diagnostic tool, easy to perform and without major complications even in patients with pulmonary involvement, with a stable clinical picture corroborating with the literature (McCarthy \& McDermaid 1999).

The mean duration of the procedure was considered short in relation to the conventional thoracotomy biopsy techniques reported in the literature. This is in part due to the good training and coordination of the surgical team, which

Table 1. Histopathological results of the biopsy with the guillotined cutting needle and the biopsy forceps and location of the lesions

\begin{tabular}{cllc}
\hline N & \multicolumn{1}{c}{ Cutting needle sample } & \multicolumn{1}{c}{ Biopsy forceps sample } & Location \\
\hline 1 & Papillary adenocarcinoma metastasis & Papillary adenocarcinoma metastasis & LCrD \\
2 & Tubulopapillary carcinoma metastasis & Tubulopapillary carcinoma metastasis & LCdD \\
3 & Leiomyosarcoma & Atelectasis, areas of necrosis & LCdE \\
4 & Chronic pyogranulomatous inflammation & Chronic pyogranulomatous inflammation & LCdD \\
5 & Adenosquamous carcinoma metastasis & Adenosquamous carcinoma metastasis & LCdD \\
6 & Cholangiocarcinoma metastasis & Cholangiocarcinoma metastasis & LCdE \\
7 & Hemangiosarcoma metastasis & Hemangiosarcoma metastasis & LCrE \\
8 & Osteosarcoma metastasis & Osteosarcoma metastasis & LCdE \\
9 & Complex carcinoma metastasis & Complex carcinoma metastasis & LCdD \\
10 & Metastasis of carcinosarcoma & Metastasis of carcinosarcoma & LCrD \\
11 & Metastasis myoepithelial carcinoma & Metastasis myoepithelial carcinoma & LMD \\
12 & Complex carcinoma metastasis & Atelectasis, areas of necrosis & LCdD, med. \\
13 & Mesothelioma & Mesothelioma & LCdE \\
14 & Pulmonary carcinoma & Pulmonary carcinoma &
\end{tabular}

$\mathrm{N}=$ patient number, $\mathrm{LCrD}=$ right cranial lobe, $\mathrm{LCdD}=$ right caudal lobe, $\mathrm{LCrE}=$ left cranial lobe, $\mathrm{LCdE}=$ left caudal lobe, $\mathrm{LMD}=$ medium right lobe, med. $=$ mediastinum . 
according to Beck et al. (2004) is essential for performing the surgical procedure, although it is important to emphasize that both the correct positioning of the animals and the adequate technical execution of the procedures are indispensable factors for the execution of the surgery.

The learning curve in video-surgery makes operative time decrease as the surgeon gains experience with the technique and becomes more familiar and adapted to the instruments and equipment (Faraco 2013). This can be observed in this study in which surgical time was reduced throughout the experiment. This finding corroborates with Santos \& Bravo Neto (2010), who affirmed that the success of a procedure requires, besides an accurate indication, technical ability, which is based on the repetition of movements and goes through a phase in which the learner acquires competence quickly, to then reach a plateau, after which no difference is observed in the gain of the abilities, although it continues to gain speed.

According to Beck et al. (2004), previous surgical planning, including the positioning of the tower, the surgical team and anesthetic is fundamental for the good progress of the procedures in the video-surgery. In the present experiment, this planning was established before all the procedures, so that the surgical team was able to carry out the surgical maneuvers in a comfortable and safe way. Regarding the positioning of the patients in the supine position, it was verified that this allowed the introduction of the trocars both through intercostal access and transdiaphragmatic paraxiphoid without major difficulties, besides allowing visualization of the mediastinum of the thoracic wall, pulmonary lobes except the dorsal face, pericardium, lymph nodes, large vessels, esophagus and diaphragm.

In all dogs included in the project, two trocars (portals) were used to access the thoracic cavity. The first portal was inserted in the intercostal region, and the second through transdiaphragmatic paraxiphoid access (Fig.3). The site of

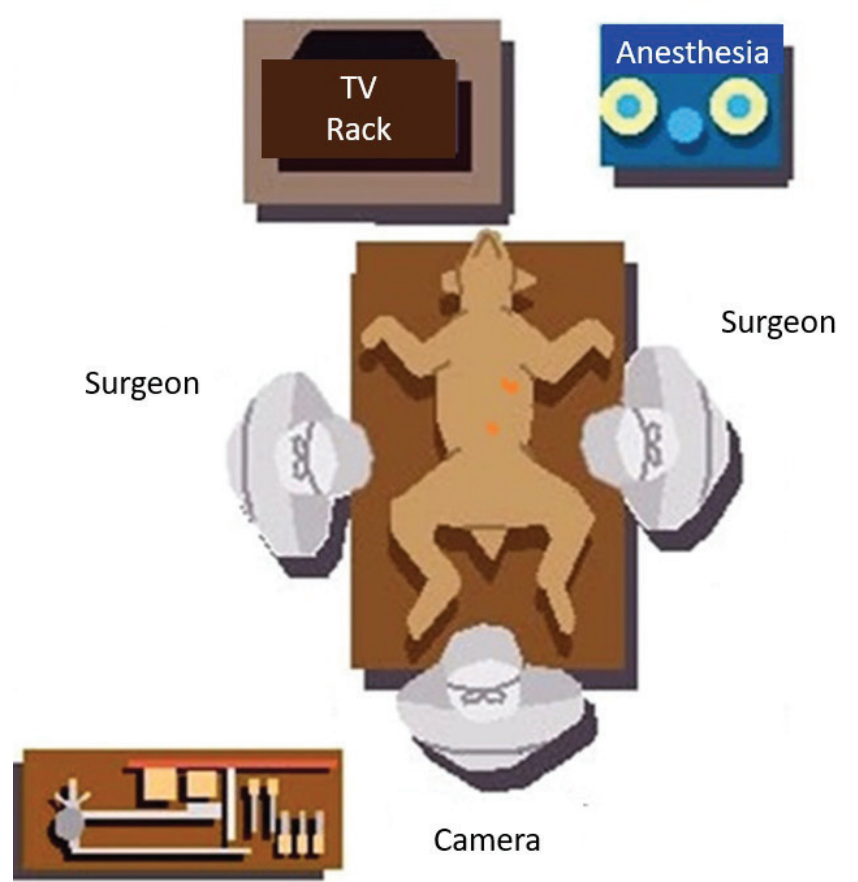

Fig.3. Schematic representation of the equipment, surgical team and positioning of the portals in the patient. choice for the insertion of the first portal was based on the thoracic radiograph, which provided an approximate idea of the location of the tumor. The objective of the first access portal was to first access the thorax near the area(s) in which the tumors were identified by the radiographic images. At the same time, the intercostal access was used to perform the previous exploration of the corresponding hemithorax and to facilitate the insertion of the transdiaphragmatic paraxiphoid portal under endoscopic visualization.

The option to insert the second portal through transdiaphragmatic paraxiphoid access guided by endoscopic intercostal visualization was safe, without the occurrence of iatrogenic lesion in any of the 14 dogs of this study, corroborating the reports of Pigatto et al. (2008) and Basso et al. (2010). However, it is noteworthy that in these studies the pneumothorax was instituted by insufflation of the thoracic cavity with $\mathrm{CO}_{2}$ which facilitated diaphragm distension and the transdiaphragmatic paraxiphoid trocar insertion safe.

In four dogs (Dog 3, 5, 6 and 7) the portal had to be reinserted into another intercostal space, different from the one planned based on radiography. It is believed that this mistake occurred due to image overlap in the radiographic examination. According to Norris et al. (2002), thoracic radiography is a good screening test, but because it does not detect lumps smaller than four millimeters and often present overlapping images it is a limited examination. Thus, the anesthetic block of two caudal and two cranial intercostal spaces was indispensable to the planned access site, in order to obtain a wider access margin.

Another fact that strengthens the radiographic examination, in relation to the identification of small pulmonary nodules and, at the same time, presents a quality of presentation of the surgical procedures, is related to the fact that in seven dogs $(50 \%)$ the number of lesions were lower than those seen during thoracoscopy. Schmiedt (2009) and Radlinsky (2014) highlight the diagnostic character of the thoracoscopic procedures as one of the advantages that this access allows. It should be noted that, according to the findings of the present study, thoracic radiography characterizes an important stage as a screening test in patients with suspicion of thoracic malignancies. However, for greater sensitivity and specificity, the thoracoscopic approach is recommended.

In this study, since dogs presented respiratory compromise, undo the negative thoracic pressure, without the additional insufflation of $\mathrm{CO}_{2}$, was the chosen option. For this, the initial approach to the thorax was performed through intercostal access. This provided greater safety, reducing the risks of iatrogenesis to the intrathoracic structures that could be caused by transdiaphragmatic paraxiphoid access, without the recommended previous pneumothorax.

The option for the initial intercostal approach, besides the safety provided in the endoscopic view of the insertion of the transdiaphragmatic trocar (2nd portal), also allowed to observe the entire diaphragm region, which cannot be performed through the cavitary visualization by the transdiaphragmatic paraxiphoid access. This maneuver was important because some dogs also had nodules on the diaphragmatic wall. The use of two $5 \mathrm{~mm}$ diameter access portals, the first intercostal and the second transdiaphragmatic paraxiphoid, proved to be a good option, regarding also to the extent of thoracic cavity exploration. The possibility of a change in the position of the 
$4 \mathrm{~mm}$ optic, alternating its insertion through the intercostal and paraxiphoid portal during the procedures allowed a greater reach both in the visual exploration as in the performance of the punctures and the pulmonary parenchyma.

The formation of pneumothorax is essential to prevent lesions of the pulmonary parenchyma at the time of the insertion of the trocar and to obtain full visualization of the intrathoracic structures (Walsh et al. 1999, Peroni et al. 2001). In this study, the divulsion of the intercostal muscles and thoracic cavity were performed with Halstead hemostatic forceps, thus reducing the negative pressure of the thorax. This maneuver provided insertion of trocars with little resistance, adequate pneumothorax and avoided possible iatrogenic lesions on the lung. These results corroborate with the study of Isakow et al. (2000) that produced pneumothorax only with musculature divulsion and perforation of the parietal pleura.

Landreneau et al. (1994) reported that intrathoracic inflation with carbon dioxide in thoracoscopic procedures is not essential and only assists the inspection of the pleural cavity by the total lung collapse that it produces and, in addition to the small distension of the cavity it promotes, enlarges the visual field of the thorax. But they can cause increased blood pressure and compromise circulatory dynamics.

The choice for transdiaphragmatic paraxiphoid access for the insertion of the endoscope allowed extensive exploration of the thoracic cavity in both hemithorax and excellent visualization of the pulmonary parenchyma, corroborating with the studies of Twedt (2002), Pigatto et al. (2008) and Basso et al. (2010). It is known that both dogs and cats may present communication between the hemithorax physiologically (Orton 1998).

Regarding the quality of the collected material, in general, satisfactory indexes of success in obtaining appropriate material for analyzes above $85 \%$ are considered satisfactory (Chojniak et al. 2011).

It is believed that in the two patients in which the samples collected were not significant, it is due to the fact that many tumors, regardless of their histological origin, present an area of peritumoral cell necrosis. Thus, larger diameter nodules tend to present their outermost layer composed only of cellular debris and necrosis (Jones et al. 2000).

The guillotined needle sample was more representative in the larger diameter neoplastic lung lesions. It is possible to observe in these the shape and the arrangement of the tumor cells, since the needle reached all the layers of the lesion. Chojniak et al. (2011) found specific histological results with a higher frequency (97\%) in the use of cutting-type needles when compared to the thin needle and reported greater success in obtaining samples in lesions larger than $40 \mathrm{~mm}$ in diameter.

Regarding the use of the biopsy forceps, Basso et al. (2010) found it difficult to section the lung tissue with forceps alone, and it was necessary to use a 40x12 needle. This was not observed in this study, since all the biopsied dogs had alterations in the pulmonary parenchyma, making it more friable and easily sectioned. Both Basso et al. (2010) and Lamounier (2006) concluded that the samples obtained by the biopsy forceps were considered satisfactory, according to the histopathological report, and it was possible to visualize the presence of lung tissue. This condition was also observed in this experiment. Regarding the healing of the biopsy site, it is believed that this occurred by second intention, probably by the deposition of fibrin buffer in the sectioned site, dispensing sutures in the pulmonary parenchyma. This can be evidenced by the absence of pneumothorax in the radiographic evaluation of the dogs 48 hours after the procedure. According to Lamounier (2006) there is a minimum air escape after the removal of pulmonary fragments of up to $0.5 \mathrm{~cm}$ in diameter, because the clamp used promotes tissue crushing.

The use of guillotine cutting needle to obtain pulmonary biopsy in dogs has not been described in the literature yet. In humans it is a technique already consolidated and of everyday use in the routine. In this study, the acquisition of histologically significant samples occurred in $100 \%$ of the dogs participating in the study was observed. Even in lesions of reduced diameter it was possible to obtain material, corroborating with Chojniak et al. (2011), whom concluded that percutaneous cutting needle biopsy has become one of the main choices for nodule and mass investigation. Its versatility allows the access of lesions in different locations of the lung, being able to be used for peripheral and deep lesions even of small dimensions, achieving $97 \%$ success in obtaining viable samples.

After the end of the procedure, thoracentesis was chosen to restore the negative pressure in the thorax. The crushing caused by the forceps, the reduced diameter of the samples collected and alteration present in the pulmonary parenchyma avoided the formation of pneumothorax, making the use of the thoracic drain unnecessary. Fossum (2008) reports that despite a low incidence, formation of pyogranulomas, pleuritis and adhesions between lung and thoracic wall may occur when thoracic drainage is used.

\section{CONCLUSIONS}

We can conclude that both biopsy collection devices tested demonstrated efficacy, but the semiautomatic guillotine cutting needle provided a better diagnostic result when compared to the biopsy forceps, especially in the collection of larger tumor nodules.

Transdiaphragmatic paraxiphoid thoracoscopy was adequate for the bilateral assessment of the chest cavity and obtaining pulmonary biopsy in dogs from any lobe of both lungs and presented as a fast and safe technique even in animals with pulmonary involvement, with a stable clinical picture.

\section{REFERENCES}

Baez J.L. \& Sorenmo K.U. 2004. Pulmonary and bronchial neoplasia, p.508-515. In: King L.G. (Ed.), Respiratory Disease in Dogs and Cats. W.B. Saunders, St Louis. <http://dx.doi.org/10.1016/B978-0-7216-8706-3.50073-6>.

Basso P.C., Raiser A.G., Brun M.V., Guizzo Junior N., Feranti J.P.S., Motta A.C., Bortolini C.E. \& Muller D.C.M. 2010. Biópsia pulmonar incisional por toracoscopia paraxifoide transdiafragmática com dois portais em cães. Pesq. Vet. Bras. 30(7):566-572. <http://dx.doi.org/10.1590/S0100736X2010000700010.

Beck C.A.C., Pippi N.L., Brun M.V., Contesini E.A., Cunha A.F., Stedile R., Bonfada A.T., Silva Filho A.P.F., Gomes K. \& Colomé L.M. 2004. Toracoscopia nas hérnias diafragmáticas: estudo experimental em cães. Ciência Rural 34(6):18571863. <http://dx.doi.org/10.1590/S0103-84782004000600029>

Chojniak R., Pinto P.N.V., Ting C.J., Cohen M.P., Guimarães M.D., Yu L.S. \& Bitencourt A.G.V.2011. Biópsia transtorácica de nódulos e massas pulmonares dirigida por tomografia computadorizada. Radiol. Bras. 44(5):315-320. <http://dx.doi.org/10.1590/S0100-39842011000500010> 
Faraco C.S. 2013. Avaliação do CentryPort ${ }^{\circledR}$ como acesso único (LessLaparoendoscopic Single-Site Surgery) na realização de criptorquidectomia laparoscópica: estudo experimental em coelhos (Oryctolagus cuniculus). Dissertação de Mestrado, Universidade Federal do Rio Grande do Sul, Porto Alegre. 90p.

Fossum T.W. 2008. Cirurgia do sistema respiratório inferior: cavidade pleural e diafragma, p.752-785. In: Fossum T.W., Johnson A.L., Schulz K.S., Seim H.B., Willard M.D., Bahr A. \& Carroll G.L. (Eds.), Cirurgia de Pequenos Animais. 3aㅡ ed. Roca, São Paulo.

Isakow K., Fowler D. \& Walsh P. 2000. Video-assisted thoracoscopic division of the ligamentum arteriosum in two dogs with persistent right aortic arch. J. Am. Vet. Med. Assoc. 217(9):1333-1336. <http://dx.doi.org/10.2460/ javma.2000.217.1333><PMid:11061385>

Jones T.C., Hunt R.D. \& King N.W. 2000. Patologia Veterinária. 6ae ed. Manole, São Paulo, p.963-990.

Lamounier A.R. 2006. Biópsia pulmonar orientada por vídeo toracoscopia em cães: estudo experimental. Dissertação de mestrado, Universidade Federal de Minas Gerais, Belo Horizonte. 64p.

Landreneau R.J., Mack M.J., Hazelrigg S.R., Naunheim K., Dowling R.D., Ritter P., Magee M.J., Nunchuck S., Keenan R.J. \& Ferson P.F. 1994. Prevalence of chronic pain after pulmonary resection by thoracotomy of video assistead thoracic surgery. J. Thorac. Cardiovasc. Surg. 107(4):1079-1066, discussion 1085-1086. <PMid:8159030>

McCarthy T.C. \& McDermaid S.L. 1999. Thoracoscopy. Vet. Clin. N. Am., Small Anim.Pract. 20(5):1341-1352. <http://dx.doi.org/10.1016/S01955616(90)50308-3>

Norris C.R., Griffey S.M., Samii V.F., Christopher M.M. \& Mellema M.S. 2002. Thoracic radiography bronchoalveolar lavage cytopathology and pulmonary parenchymal histopathology: acomparison of diagnostic results in 11 cats. J. Am. Vet. Anim. Hosp. Assoc. 38(4):337-345. <http://dx.doi. org/10.5326/0380337><PMid:12118687>.

Orton E.C. 1998. Pleura e espaço pleural, p.469-489. In: Slatter D. (Ed.), Manual de Cirurgia de Pequenos Animais. Vol.1. 3a ed. Manole, São Paulo.

Peroni J.F., Horner N.T., Robinson N.E. \& Stick J.A. 2001. Equine thoracoscopy: normal anatomy and surgical technique. Equine Vet. J. 33(3):231-237. <http://dx.doi.org/10.2746/042516401776249688><PMid:11352343>
Pigatto J., Brun M.V., Barcellos L.J.G., Rausch S.F., Phol V.H., Feranti J.P.S. \& Guedes R.L. 2008. Produção de pneumotórax em cães e manejo por toracoscopia paraxifoide transdiafragmática. Ciência Rural 38(8):2210-2217.<http:// dx.doi.org/10.1590/S0103-84782008000800019>

Potter L. \& Hendrickson D.A. 1999. Therapeutic video-assisted thoracic surgery, p.169-187. In: Freeman L.J. (Ed.), Veterinary Endosurgery. Mosby, Philadelphia.

Radlinsky M. 2014. Thoracoscopy in the cat: a up-and-coming diagnostic and therapeutic procedure. J. Feline Med. Surg. 16(1):27-33. <http://dx.doi. org/10.1177/1098612X13516569><PMid:24361947>

Reineiro C.R. \& Cohn L.A. 2007. Interstitial lung diseases. Vet. Clin. N. Am., Small Anim. Pract. 37(5):937-947. <http://dx.doi.org/10.1016/j. cvsm.2007.05.008>

Santos E.G. \& Bravo Neto G.P. 2010. Curva de aprendizado e lesões iatrogênicas em colecistectomias vídeo laparoscópicas. Revta Col. Bras. Cir. 37(3):184189. <http://dx.doi.org/10.1590/S0100-69912010000300005>

Saviano M.S. \& Tazzioli G. 1998. Video thoracoscopic surgery, diagnosis and treatment of lung nodules. World J. Surg. 15(6):21-24.

Schmiedt C. 2009. Small animal exploratory thoracoscopy. Vet. Clin. N. Am., Small Anim. Pract. 39(5):953-964. <http://dx.doi.org/10.1016/j. cvsm.2009.05.007><PMid:19683654>

Solli P. \& Spaggiari L. 2007. Indications and developments of video-assisted thoracic surgery in the treatment of lung cancer. Oncologist 12(10):1205-1214. <http://dx.doi.org/10.1634/theoncologist.12-10-1205><PMid:17962614>

Twedt D.C. 2002. Diagnostic toracoscopy. Western Veterinary Conference, Denver, C0, p.34-39. (Resumo)

Walsh P.J., Remedios A.M., Ferguson J.F., Walker D.D., Cantwell S. \& Duke T. 1999. Thoracoscopic versus open partialpericardectomy in dogs: comparison of postoperative pain and morbidity. Vet. Surg. 28(6):472-479. <http:// dx.doi.org/10.1111/j.1532-950X.1999.00472.x><PMid:10582745>

Wilson D.W. \& Dungworth D.L. 2002. Tumors of the respiratory tract, p.365399. In: Meuten D.J. (Ed), Tumors in Domestic Animals. 4th ed. Blackwell Publishing Company, Ames.

Withrow S.J. 2013. Lung cancer, p.432-453. In: Vail D.M. \& Withrow S.J. (Eds), Withrow and MacEwen's Small Animal Clinical Oncology. 5th ed. Saunders Elsevier, Missouri. 